\title{
Comparison of Three Real-Time PCR Assays Targeting the SSU rRNA Gene, the COWP Gene and the DnaJ-Like Protein Gene for the Diagnosis of Cryptosporidium spp. in Stool Samples
}

\author{
Felix Weinreich ${ }^{1}{ }^{\oplus}$, Andreas Hahn ${ }^{2}{ }^{\oplus}$, Kirsten Alexandra Eberhardt ${ }^{3,4}{ }^{\oplus}$, Torsten Feldt ${ }^{5}$, Fred Stephen Sarfo ${ }^{6}$, \\ Veronica Di Cristanziano ${ }^{7} \mathbb{B}$, Hagen Frickmann ${ }^{1,2,+}+\mathbb{D}$ and Ulrike Loderstädt ${ }^{8, *,+}$ \\ 1 Department of Microbiology and Hospital Hygiene, Bundeswehr Hospital Hamburg, \\ 20359 Hamburg, Germany; felixweinreich@bundeswehr.org (F.W.); frickmann@bnitm.de (H.F.) \\ 2 Department of Medical Microbiology, Virology and Hygiene, University Medicine Rostock, \\ 18057 Rostock, Germany; andreas.hahn@uni-rostock.de \\ 3 Institute of Transfusion Medicine, University Medical Center Hamburg-Eppendorf, \\ 20251 Hamburg, Germany; ki.eberhardt@uke.de \\ 4 Department of Tropical Medicine, Bernhard Nocht Institute for Tropical Medicine, 20359 Hamburg, Germany \\ 5 Department of Gastroenterology, Hepatology and Infectious Diseases, University Medical Center Düsseldorf, \\ 40225 Düsseldorf, Germany; Torsten.Feldt@med.uni-duesseldorf.de \\ 6 Department of Medicine, Kwame Nkrumah University of Science and Technology, Kumasi 00233, Ghana; \\ fsarfo.chs@knust.edu.gh \\ check for \\ updates \\ Citation: Weinreich, F.; Hahn, A.; \\ Eberhardt, K.A.; Feldt, T.; Sarfo, F.S.; \\ Di Cristanziano, V.; Frickmann, H.; \\ 7 Institute of Virology, Faculty of Medicine and University Hospital of Cologne, University of Cologne, \\ 50935 Cologne, Germany; veronica.di-cristanziano@uk-koeln.de \\ 8 Department of Hospital Hygiene \& Infectious Diseases, University Medicine Göttingen, \\ 37075 Göttingen, Germany \\ * Correspondence: ulrike.loderstaedt1@med.uni-goettingen.de; Tel.: +49-551-3965709 \\ + Hagen Frickmann and Ulrike Loderstädt equally contributed to this work.
} Loderstädt, U. Comparison of Three Real-Time PCR Assays Targeting the SSU rRNA Gene, the COWP Gene and the DnaJ-Like Protein Gene for the Diagnosis of Cryptosporidium spp. in Stool Samples. Pathogens 2021, 10, 1131. https://doi.org/10.3390/ pathogens10091131

Academic Editor: Collette Bromhead

Received: 14 August 2021

Accepted: 2 September 2021

Published: 2 September 2021

Publisher's Note: MDPI stays neutral with regard to jurisdictional claims in published maps and institutional affiliations.

Copyright: (c) 2021 by the authors. Licensee MDPI, Basel, Switzerland. This article is an open access article distributed under the terms and conditions of the Creative Commons Attribution (CC BY) license (https:/ / creativecommons.org/licenses/by/ $4.0 /)$.
Abstract: As qualified microscopy of enteric parasitoses as defined by high diagnostic accuracy is difficult to maintain in non-endemic areas due to scarce opportunities for practicing with positive sample materials, molecular diagnostic options provide less investigator-dependent alternatives. Here, we compared three molecular targets for the real-time PCR-based detection of Cryptosporidium spp. From a population of 1000 individuals comprising both Ghanaian HIV (human immunodeficiency virus) patients and military returnees after deployment in the tropics, stool samples were assessed for Cryptosporidium spp. by real-time PCR targeting the small subunit ribosomal RNA (SSU rRNA) gene, the Cryptosporidium oocyst wall (COWP) gene, and the DnaJ-like protein gene (DnaJ), respectively. In declining order, sensitivity of $100 \%$ for the SSU rRNA gene PCR, $90.0 \%$ for the COWP PCR and $88.8 \%$ for the DnaJ PCR, respectively, as well as specificity of $99.6 \%$ for the COWP PCR and 96.9\% for both the SSU rRNA gene PCR and the DnaJ PCR, respectively, were recorded. Substantial agreement (kappa value 0.663 ) between the three assays was observed. Further, an accuracy-adjusted Cryptosporidium spp. prevalence of $6.0 \%$ was calculated for the study population. In conclusion, none of the assessed real-time PCR assays were associated with perfect test accuracy. However, a combination of highly sensitive SSU rRNA gene PCR for screening purposes and more specific COWP PCR for confirmatory testing should allow reliable diagnosis of Cryptosporidium spp. in stool samples even in low prevalence settings.

Keywords: Cryptosporidium spp.; real-time PCR; test comparison; latent class analysis; sensitivity; specificity; diagnostic accuracy

\section{Introduction}

Human cryptosporidiosis, which typically affects immunocompromised patients, has traditionally been diagnosed with acid-fast staining and subsequent microscopical assessment [1-4]. However, skilful microscopy is difficult to maintain in non-endemic settings [5], 
resulting in limited diagnostic accuracy even in European reference centres [6]. There, molecular diagnostic approaches like real-time PCR are widely applicable as standard diagnostic procedures with a high degree of automatization in the meantime. Therefore, less investigator-dependent modern molecular diagnostic assays for the detection of Cryptosporidium spp. have been shown to be more reliable compared to microscopical or antigen-based diagnosis of human cryptosporidiosis in numerous studies [7-77]. The sensitivity of molecular assays targeting Cryptosporidium spp. is influenced by factors like the mode of nucleic acid extraction as well as by the stage of the life cycle of the parasite [78-85]. In contrast, attribution of etiological relevance of detected Cryptosporidium spp. DNA in individuals in high prevalence settings can be challenging [86-90]. Due to the partly inconsistent results regarding PCR accuracy [7-77], diagnostic standardization is ongoing.

Although this assessment does not address challenges of the molecular diagnosis of Cryptosporidium spp. in human samples or its medical interpretation, such as cycle stage dependence, optimization of nucleic acid extraction or attribution of etiological relevance of Cryptosporidium spp.-specific DNA-detections, it focuses on another aspect of diagnostic standardization: the choice of the molecular target structure by conducting a comparative head-to-head in vitro assessment with human sample materials.

In detail, the aim of the study presented here was to contribute to the standardization of Cryptosporidium spp.-specific real-time PCR assays by a comparative evaluation of three commonly chosen target genes, namely the small subunit ribosomal RNA (SSU rRNA) gene, the Cryptosporidium oocyst wall (COWP) gene, and the DnaJ-like protein gene (DnaJ), respectively $[48,51,91-93]$. Those target sequences were chosen because they have been frequently applied in Cryptosporidium spp.-specific molecular assays in the past [7-70,91-93] and so the comparative assessment of assays targeting them might be of interest for many laboratories and assay producers. The assessment was performed as a test comparison without a reference standard with 1000 residual DNA aliquots from stool samples with a high pretest-probability of being positive for Cryptosporidium spp. DNA [94] applying latent class analysis (LCA) $[95,96]$.

\section{Materials and Methods}

\subsection{Study Population}

Acquired from Ghanaian HIV patients $(n=905)$ [94,97-99] and German soldiers after returning from tropical deployments $(n=95)$ [98], a total of 1000 residual nucleic acid extractions from stool samples were included in the assessments. All residual stool samples were collected between 7 and 14 years prior to the test comparisons for diagnostic purposes and stored frozen at $-80^{\circ} \mathrm{C}$. Thereby, microscopic results were not available, so the test comparisons were performed without a reference standard. In line with the ethical clearance obtained for the test comparisons, patient-specific data like age, sex or clinical history could not be presented, which is an admitted violation of the STARD (Standards for Reporting Diagnostic Accuracy) criteria [100].

\subsection{Nucleic Acid Extraction and Real-Time PCR Assays}

Nucleic acid extraction was performed by applying the QIAamp stool DNA mini kit (Qiagen, Hilden, Germany) as described by the manufacturer. The eluates were stored at $-80^{\circ} \mathrm{C}$ prior to the PCR analysis. Three real-time in house PCR assays for Cryptosporidium spp. targeting a 159-base pair sequence of the small subunit ribosomal RNA (SSU rRNA) gene, a 151-base pair sequence of the Cryptosporidium oocyst wall (COWP) gene, and a 138-base pair sequence of the DnaJ-like protein gene (DnaJ), respectively [48,51,91-93], were performed with all samples on magnetic induction cyclers (MIC, Bio Molecular Systems Ltd., London, UK). The applied oligonucleotides are shown in Table 1. 
Table 1. Applied oligonucleotides of the compared Cryptosporidium spp.-specific real-time PCR assays.

\begin{tabular}{|c|c|c|c|c|c|}
\hline $\begin{array}{c}\text { Forward } \\
\text { Primer Name }\end{array}$ & $\begin{array}{c}\text { Forward } \\
\text { Primer Sequence }\end{array}$ & $\begin{array}{c}\text { Reverse } \\
\text { Primer Name }\end{array}$ & $\begin{array}{c}\text { Reverse } \\
\text { Primer Sequence }\end{array}$ & Probe Name & Probe Sequence \\
\hline \multicolumn{6}{|c|}{ SSU rRNA gene PCR according to [51] } \\
\hline JVAF & $\begin{array}{c}5^{\prime} \text {-ATGACGGG } \\
\text { TAACGGGGAAT-3' }\end{array}$ & JVAR & $\begin{array}{l}\text { 5'-CCAATTACAAA } \\
\text { ACCAAAAAGTCC-3' }\end{array}$ & JVAP18S & $\begin{array}{c}\text { 5'-CY3-CGCGCCTGCTGC } \\
\text { CTTCCTTAGATG-BHQ-2-3' }\end{array}$ \\
\hline \multicolumn{6}{|c|}{ DnaJ-like protein gene according to [48] } \\
\hline DnaJ F & $\begin{array}{c}5^{\prime} \text {-CGCTTCTCTA } \\
\text { GCCTTTTCATGA-3' }\end{array}$ & DnaJ R & $\begin{array}{l}\text { 5'-CTTCACGTG }^{\prime} \\
\text { TGTTTGCCAAT-3' }\end{array}$ & DnaJ P & $\begin{array}{c}5^{\prime}-\mathrm{CY}^{\prime}- \\
\text { CCAATCACAGAATCAT } \\
\text { CAGAATCGACTGGTATC- } \\
\text { BHQ-2-3' }\end{array}$ \\
\hline \multicolumn{6}{|c|}{ COWP gene PCR according to [92] } \\
\hline COWP P702 F & $\begin{array}{l}\text { 5'-CAAATTGATAC } \\
\text { CGTTTGTCCTTCTG-3' }\end{array}$ & COWP P702 R & $\begin{array}{l}\text { 5'-GGCATGTCGAT } \\
\text { TCTAATTCAGCT-3' }\end{array}$ & COWP P702 P & $\begin{array}{c}\text { 5'-ROX5-TGCCATACATTGTT } \\
\text { GTCCTGACAAATTGAAT- } \\
\text { BHQ-2-3' }\end{array}$ \\
\hline
\end{tabular}

The reaction mix of each assay comprised the HotStarTaq Mastermix (Qiagen, Hilden, Germany) and a final $\mathrm{Mg}^{2+}$ concentration of $5 \mathrm{mM}$. For the different assays, the concentrations were $300 \mathrm{nM}$ for the primers and $200 \mathrm{nM}$ for the probe in the DnaJ-like protein genespecific assay, $300 \mathrm{nM}$ for the primers and $25 \mathrm{nM}$ for the probe in the COWP gene-specific assay as well as $250 \mathrm{nM}$ for the primers and $300 \mathrm{nM}$ for the probe in the SSU rRNA genespecific assay, respectively. The PCR reactions were run in $20 \mu \mathrm{L}$ volumes including $2 \mu \mathrm{L}$ residual DNA eluate. Each PCR run included a negative control based on PCR-grade water and a positive control based on a plasmid with inserted Cryptosporidium spp. sequences according to the NCBI GenBank accession numbers AY458612, AF248743, and AF188110, respectively, in a pEX-A128 vector backbone (see Table A1 for sequence details). Sample inhibition was assessed by applying a Phocid herpes virus DNA-specific real-time PCR as described elsewhere [101]. The limits of detection of the three real-time PCR assays were calculated based on a dilution series of the positive control plasmid applying the software SciencePrimer.com (http://scienceprimer.com/copy-number-calculator-for-realtime-pcr, last accessed on 13 July 2021). Limits of detection less than 10 copies per $\mu \mathrm{L}$ eluate were recorded for all real-time PCR assays. In detail, a limit of detection of 7.7 target genes per $\mu \mathrm{L}$ eluate was recorded based on the dilution series for all assays assessed. The PCR reaction profile was as follows: Initial heating to $95^{\circ} \mathrm{C}$ for $15 \mathrm{~min}$ followed by 45 cycles of denaturation for $15 \mathrm{~s}$ at $95^{\circ} \mathrm{C}$ and annealing as well as amplification for $60 \mathrm{~s}$ at $60^{\circ} \mathrm{C}$ with subsequent final cooling to $40^{\circ} \mathrm{C}$ for $20 \mathrm{~s}$.

\subsection{Exclusion Criteria and Statistical Assessment}

Inhibited samples as indicated by the inhibition control PCR [101] were excluded from the analyses. Applying latent class analysis (LCA) $[95,96]$, sensitivity and specificity of each real-time PCR assay as well as accuracy-adjusted prevalence of the study population were estimated. Fleiss' kappa for the agreement of the different assays was calculated by applying the categories as previously described [102]. In addition, a comparison of the recorded cycle threshold $(C t)$ values was conducted. The software Stata/IC 15.1 for Mac 64-bit Intel (College Station, TX, USA) was used for the calculations.

\section{Results}

3.1. Agreement Kappa between the Real-Time PCR Assays, LCA-Based Calculation of Sensitivity as Well as Specificity of the Assays, and Accuracy-Adjusted Prevalence in the Study Population

From a total of 1000 samples, 33 had to be excluded from further assessment because of recorded PCR inhibition. Overall, two inhibited samples were from the subpopulation of the 95 German soldiers, and the other 31 were from the 905 Ghanaian HIV patients. Within the remaining 967 samples, 56 (5.79\%) positive PCR signals were recorded in COWP PCR, $80(8.27 \%)$ in DnaJ PCR and $86(8.89 \%)$ in SSU rRNA gene PCR. Of note, all positive results 
were recorded from samples from Ghanaian HIV patients. Thereby, agreement between the three compared Cryptosporidium spp.-specific real-time PCR assays was substantially in line with the interpretation standards as suggested by Landis and Koch [102] with a Fleiss' kappa value of 0.663 . As calculated by applying LCA, the test accuracy-adjusted Cryptosporidium spp. prevalence within the assessed study population was $6.0 \%$ (Table 2).

Table 2. Agreement kappa between the compared real-time PCR assays as well as sensitivity, specificity and accuracy-adjusted prevalence as calculated with latent class analysis (LCA).

\begin{tabular}{|c|c|c|c|c|c|}
\hline Assay & $n$ & Positives (\%) & $\begin{array}{c}\text { Sensitivity } \\
(0.95 \mathrm{CI})\end{array}$ & $\begin{array}{l}\text { Specificity } \\
\text { (0.95 CI) }\end{array}$ & $\begin{array}{c}\text { Kappa } \\
\text { (0.95 CI) }\end{array}$ \\
\hline DnaJ PCR & 967 & $80(8.27)$ & $\begin{array}{c}0.888 \\
(0.770,0.949)\end{array}$ & $\begin{array}{c}0.969 \\
(0.955,0.978)\end{array}$ & \\
\hline COWP PCR & 967 & $56(5.79)$ & $\begin{array}{c}0.900 \\
(0.773,0.960)\end{array}$ & $\begin{array}{c}0.996 \\
(0.989,0.998)\end{array}$ & $\begin{array}{c}0.663 \\
(0.574,0.744)\end{array}$ \\
\hline $\begin{array}{c}\text { SSU rRNA } \\
\text { gene PCR }\end{array}$ & 967 & $86(8.89)$ & $\begin{array}{c}1 \\
(0,1)\end{array}$ & $\begin{array}{c}0.969 \\
(0.956,0.979)\end{array}$ & \\
\hline $\begin{array}{c}\text { Prevalence } \\
(0.95 \mathrm{CI})\end{array}$ & \multicolumn{5}{|c|}{$0.060(0.047,0.078)$} \\
\hline
\end{tabular}

$0.95 \mathrm{CI}=95 \%$-confidence intervals. $n=$ numbers.

Focusing on sensitivity as calculated with LCA, optimum sensitivity of 100\% was recorded for SSU rRNA gene PCR followed by COWP PCR with $90.0 \%$ and DnaJ PCR with $88.8 \%$, respectively. Regarding specificity, in contrast, COWP PCR scored best with $99.6 \%$, while a lower specificity of $96.9 \%$ was calculated with LCA for both DnaJ PCR and SSU rRNA PCR (Table 2).

When focusing on the matches and mismatches between the different PCR assays, all three PCRs were positive in 47 samples and all three PCRs were negative in 851 cases. When directly comparing the positive results between the individual assays, the number of mismatches ranged between 3 and 33. In comparison, the numbers of matches between different assays ranged from 47 to 86 for positive results and from 854 to 911 for negative results. Details are provided in Table 3.

Table 3. Cross-table detailing mismatches between the different PCR assays. Green = matching results. Red $=$ mismatching results. Black $=$ not filled in to avoid repetition.

\begin{tabular}{cccccccc}
\hline & & \multicolumn{2}{c}{ DnaJ PCR } & \multicolumn{2}{c}{ COWP PCR } & \multicolumn{2}{c}{$\begin{array}{c}\text { SSU rRNA } \\
\text { Gene PCR }\end{array}$} \\
\cline { 2 - 8 } & & Negative & Positive & Negative & Positive & Negative & Positive \\
\hline \multirow{2}{*}{ DnaJ PCR } & negative & 887 & 0 & & & & \\
\cline { 2 - 8 } & positive & 0 & 80 & & & & \\
\hline \multirow{2}{*}{ COWP PCR } & negative & 878 & 33 & 911 & 0 & & \\
\cline { 2 - 8 } & positive & 9 & 47 & 0 & 56 & & \\
\hline \multirow{2}{*}{$\begin{array}{c}\text { SSU rRNA } \\
\text { gene PCR }\end{array}$} & negative & 854 & 27 & 878 & 3 & 881 & 0 \\
\cline { 2 - 8 } & positive & 33 & 53 & 33 & 53 & 0 & 86 \\
\hline
\end{tabular}

\subsection{Comparison of the Cycle Threshold (Ct) Values between the Assays}

Comparing the recorded cycle threshold values, highest mean and median $\mathrm{Ct}$ values were recorded for DnaJ PCR (Table 4), for which the lowest sensitivity was also calculated (Table 2). The mean and median Ct values of COWP PCR and SSU rRNA gene PCR, in contrast, were virtually identical. Even the difference between DnaJ PCR and COWP PCR or SSU rRNA gene PCR was quite low, ranging between just 1 and $2 \mathrm{Ct}$ steps. The standard deviation ranges of the $\mathrm{Ct}$ values of all compared PCRs were also quite similar, varying between 3.84 and 4.87 (Table 4). 
Table 4. Recorded cycle threshold (Ct) values of the real-time PCR assays.

\begin{tabular}{cccc}
\hline Assay & $\boldsymbol{n}$ & Mean (SD) & Median (Min, Max) \\
\hline DnaJ PCR & 80 & $34.14(4.87)$ & $34.41(22.12,41.50)$ \\
\hline COWP PCR & 56 & $32.14(3.84)$ & $33.16(22.30,38.07)$ \\
\hline SSU rRNA gene PCR & 86 & $32.09(4.31)$ & $33.21(20.38,39.16)$ \\
\hline$n=$ numbers. SD $=$ standard deviation. Min = minimum. Max $=$ maximum.
\end{tabular}

$n=$ numbers. $\mathrm{SD}=$ standard deviation. Min $=$ minimum. Max $=$ maximum.

\section{Discussion}

The study was performed to comparably assess the diagnostic accuracy of three realtime PCRs targeting Cryptosporidium spp. based on three target genes, i.e., the small subunit ribosomal RNA (SSU rRNA) gene, the Cryptosporidium oocyst wall (COWP) gene, and the DnaJ-like protein gene (DnaJ), respectively [48,51,91-93], without a reference standard applying latent class analysis (LCA). Interestingly, substantial agreement [102] with a kappa value of 0.663 between the diagnostic assays indeed confirmed a common targeted meta-structure, but is yet far away from a perfect matching. In the LCA-based estimation indicating sensitivity ranging from $88.8 \%$ to $100 \%$ and specificity ranging from $96.9 \%$ to $99.6 \%$, Cryptosporidium spp. was the common meta-structure addressed by the three assays with specificity for three different target sequences.

Close-to-perfect specificity (>99\%) could be shown for the COWP PCR assay only, while calculated specificity for the SSU rRNA gene assay and the DnaJ PCR assay were still acceptable, but nevertheless imperfect, with values $>95 \%$. As specificity depends on the conservation level of the target sequence, limited numbers of available reference sequences, in particular for the DnaJ-like protein gene [91], imply uncertainty regarding their diagnostic reliability. Accordingly, in-vitro evaluations like the one described here are unavoidable. Regarding sensitivity, a close-to-perfect value of virtually $100 \%$ was recorded for the SSU rRNA gene PCR only, while sensitivity values of $90 \%$ as estimated for the COWP PCR and even slightly below $90 \%$ as estimated for the DnaJ PCR have to be considered as suboptimal for diagnostic purposes. Although previous assessments suggested even worse sensitivity of about $50 \%$ for microscopy-based identification of Cryptosporidium spp. in human stool samples [7], a situation with one out of ten samples positive for Cryptosporidium spp.-specific DNA going undetected still leaves room for improvement.

Of note, a total of $33 / 1000$ samples (3.3\%) had to be excluded from the assessment due to inhibition of the PCR reaction. Thereby, a higher proportion of inhibition was recorded in the samples collected under resource-limited tropical conditions compared to the samples collected under standardized conditions from the assessed German soldiers. Among the latter, the inhibition rate was close to $2 \%$, which matched the expectations from a previous assessment [103] as well as the authors' experience from the diagnostic routine. Considering the abovementioned sensitivity limits of microscopy as compared to real time PCR [7], the sensitivity benefit due to real-time PCR is still obvious.

In summary, none of the assessed assays showed optimum accuracy for the detection of the targeted meta-structure Cryptosporidium spp. Due to their imperfect specificity, SSU rRNA gene PCR and DnaJ PCR results should be confirmed by COWP PCR showing high specificity, while the highly sensitive SSU rRNA gene PCR is an interesting candidate for an initial screening. However, one has to keep in mind that the reduced specificity can result in deleterious consequences for the positive predictive value in case of screenings in populations with a low pretest probability due to a low prevalence in line with Bayes' theorem [95]. Therefore, confirmatory testing applying the more specific COWP PCR is advisable in case of screening assessments in low prevalence settings. A likely combination could comprise the SSU rRNA gene PCR as a highly sensitive screening approach in order not to overlook infections as well as COWP PCR-based confirmatory testing for surveillance in low prevalence settings. When applying this combination of real-time PCR assays, a possible case of a Cryptosporidium spp. infection would be defined by a solitary positive 
SSU rRNA gene PCR, while a confirmed case would demand confirmation by a positive result in COWP PCR as well. The associated additional effort will be negligible, because the identical run conditions of both assays allow their application in single-tube or multi-tube multiplexing approaches, if the availability of the required technical equipment and trained personnel can be considered as guaranteed.

Interestingly, the lower sensitivity of COWP PCR compared to SSU rRNA gene PCR cannot be explained by cycle threshold value differences. On the contrary, the recorded cycle threshold values of both assays were quite similar. Although the SSU rRNA gene is a multicopy target, which potentially accounts for slightly better sensitivity, the low number of genomic repeats may explain the recorded similar $\mathrm{Ct}$ values. Hypothetically, the observed test characteristics were affected by the performed standard nucleic acid extraction with the column-based QIAamp DNA stool mini kit (Qiagen, Hilden, Germany), because better DNA yields in the case of harsher bead-beating-based extraction schemes have been described [78-81]. However, such a hypothetically reduced target DNA yield should have influenced all assessed real-time PCR assays in the same direction, although stochastic amplification in the limit-of-detection range may be considered.

As expected for immunocompromised individuals from tropical settings [1-3], a considerable accuracy-adjusted prevalence of $6.0 \%$ could be calculated by LCA for the Ghanaian HIV patients. Well in line with a previous surveillance study [104], Cryptosporidium spp. DNA was absent in stool samples of German military returnees from tropical deployments. Apart from small outbreaks at tropical deployment sites as reported previously from the European Union Training Mission (EUTM) in Mali [105], Cryptosporidium spp. was virtually absent in the gut of German soldiers after deployment [106].

This study has a number of limitations. First of all, lacking microscopic results for most residual samples made it necessary to perform a test comparison without a reference standard applying LCA. Second, a relatively low proportion of positive samples in spite of a high pretest probability in the assessed sample collection resulted in broad 95\%-confidence intervals. Third, funding limits did not allow sequencing of PCR amplicons, so individual decisions on whether a discrepancy was due to sensitivity or specificity issues was impossible and test accuracy had to be estimated based on mathematical paradigms alone. Fourth, the wide age range of the assessed sample sets might have influenced the results. As, however, sample quality was the same for all compared real-time PCR assays, this limitation more likely had an impact on the prevalence estimations rather than on the assay comparison itself.

\section{Conclusions}

Imperfect test accuracy was recorded for all real-time PCR assays assessed. However, optimum sensitivity close to $100 \%$ for the detection of Cryptosporidium spp. could be recorded for the SSU rRNA gene PCR and excellent specificity of $99.6 \%$ for the COWP PCR. If highly sensitive SSU rRNA gene PCR is applied for screening purposes and more specific COWP PCR for confirmation testing, reliable screening results should be possible even in the case of application in low prevalence settings. The results of this study may be of interest for diagnostic microbiologists who clinically interpret the results of Cryptosporidium spp. PCRs based on the addressed target sequences. To the authors' best knowledge, a respective direct head-to-head comparison of such frequently applied Cryptosporidium spp.-specific target sequences from the diagnostic routine has not been provided so far.

Of course, the assessment addressed the choice of the target sequence only. Other topics like the further standardization of the nucleic acid extraction [78-82] and of the clinical interpretation of positive real-time PCR signals [86-90] still remain unsolved and require additional investigations. Further, it is also advisable to confirm the results obtained in this assessment with a study design in line with the abovementioned STARD criteria [100]. 
Author Contributions: Conceptualization, H.F. and U.L.; methodology, F.W., H.F. and A.H.; software, F.W. and A.H.; validation, F.W.; formal analysis, A.H.; investigation, F.W. and A.H.; resources, H.F., U.L., K.A.E., T.F., F.S.S. and V.D.C.; data curation, F.W. and A.H.; writing—original draft preparation, H.F.; writing-review and editing, F.W., A.H., K.A.E., T.F., F.S.S., V.D.C., H.F. and U.L.; supervision, H.F.; project administration, H.F.; funding acquisition, H.F. and U.L. All authors have read and agreed to the published version of the manuscript.

Funding: The study was funded by grant 36K2-S-45 1922, “Evaluation and optimization of molecular diagnostic tests for tropical parasitic diseases for surveillance and risk assessment purposes in tropical deployment settings-a German-French cooperation project between the German Armed Forces Hospital Hamburg and the Military Hospital Laveran, Marseille" of the German Ministry of Defense (MoD) awarded to Hagen Frickmann. We acknowledge support by the Open Access Publication Funds of the Göttingen University.

Institutional Review Board Statement: Ethical clearance as obtained by the medical association of Hamburg, Germany, (reference number: WF-011/19, obtained on 11 March 2019) allowed anonymous use of residual sample materials for test comparison purposes without informed consent. The study was conducted according to the guidelines of the Declaration of Helsinki.

Informed Consent Statement: Not applicable.

Data Availability Statement: All relevant data are provided within the manuscript. Raw data can be provided on reasonable request.

Acknowledgments: Simone Priesnitz and Annett Michel are gratefully acknowledged for excellent technical assistance.

Conflicts of Interest: The authors declare no conflict of interest. The funders had no role in the design of the study; in the collection, analyses, or interpretation of data; in the writing of the manuscript, or in the decision to publish the results.

\section{Appendix A}

Table A1. Sequence inserts for the positive control plasmid.

Positive Control Insert Based on Cryptosporidium spp. Sequences According to the NCBI GenBank Accession Numbers AY458612, AF248743 and AF188110.

GAATTCTACCGTGGCAATGACGGGTAACGGGGAATTAGGGTTCGATTCCGGAGAGGGAGCCTGAGAAA CGGCTACCACATCTAAGGAAGGCAGCAGGCGCGCAAATTACCCAATCCTAATACAGGGAGGTAGTGACA AGAAATAACAATACAGGACTTTTTGGTTTTGTAATTGGAATGAGTTAAGAATTCATTAATTCAACAAATTG ATACCGTTTGTCCTTCTGGTTTTGTTGAAGAAGGAAATAGATGTGTTCAATATCTCCCTGCAAATAAAATC TGTCCTCCTGGATTCAATTTGTCAGGACAACAATGTATGGCACCAGAATCAGCTGAATTAGAATCGACAT GCCCACCTAATTCGAATTCCTACGTCTAACTTCACGTGTGTTTGCCAATGCATATGAAGTTATAGGGATAC CAGTCGATTCTGATGATTCTGTGATTGGTAAAAAGTATAGAAAGCTCTCATTATTGATCCACCCTGATAAG ACAAGTCATGAAAAGGCTAGAGAAGCGTTTGAAATACGAATTC

\section{References}

1. Bouzid, M.; Hunter, P.R.; Chalmers, R.M.; Tyler, K.M. Cryptosporidium pathogenicity and virulence. Clin. Microbiol. Rev. 2013, 26, 115-134. [CrossRef]

2. Crawford, F.G.; Vermund, S.H. Human cryptosporidiosis. Crit. Rev. Microbiol. 1988, 16, 113-159. [CrossRef]

3. Hoepelman, I.M. Human cryptosporidiosis. Int. J. STD AIDS 1996, 7 (Suppl. 1), 28-33. [CrossRef]

4. Hagen, R.M.; Loderstaedt, U.; Frickmann, H. An evaluation of the potential use of Cryptosporidium species as agents for deliberate release. J. R. Army Med. Corps. 2014, 160, 289-294. [CrossRef]

5. van Lieshout, L.; Roestenberg, M. Clinical consequences of new diagnostic tools for intestinal parasites. Clin. Microbiol. Infect. 2015, 21, 520-528. [CrossRef]

6. Utzinger, J.; Botero-Kleiven, S.; Castelli, F.; Chiodini, P.L.; Edwards, H.; Köhler, N.; Gulletta, M.; Lebbad, M.; Manser, M.; Matthys, B.; et al. Microscopic diagnosis of sodium acetate-acetic acid-formalin-fixed stool samples for helminths and intestinal protozoa: A comparison among European reference laboratories. Clin. Microbiol. Infect. 2010, 16, 267-273. [CrossRef]

7. Frickmann, H.; Hoffmann, T.; Köller, T.; Hahn, A.; Podbielski, A.; Landt, O.; Loderstädt, U.; Tannich, E. Comparison of five commercial real-time PCRs for in-vitro diagnosis of Entamoeba histolytica, Giardia duodenalis, Cryptosporidium spp., Cyclospora cayetanensis, and Dientamoeba fragilis in human stool samples. Travel. Med. Infect. Dis. 2021, 41, 102042. [CrossRef] 
8. Laude, A.; Valot, S.; Desoubeaux, G.; Argy, N.; Nourrisson, C.; Pomares, C.; Machouart, M.; Le Govic, Y.; Dalle, F.; Botterel, F.; et al. Is real-time PCR-based diagnosis similar in performance to routine parasitological examination for the identification of Giardia intestinalis, Cryptosporidium parvum/Cryptosporidium hominis and Entamoeba histolytica from stool samples? Evaluation of a new commercial multiplex PCR assay and literature review. Clin. Microbiol. Infect. 2016, 22, e1-e190.

9. Paulos, S.; Saugar, J.M.; de Lucio, A.; Fuentes, I.; Mateo, M.; Carmena, D. Comparative performance evaluation of four commercial multiplex real-time PCR assays for the detection of the diarrhoea-causing protozoa Cryptosporidium hominis/parvum, Giardia duodenalis and Entamoeba histolytica. PLoS ONE 2019, 14, e0215068. [CrossRef] [PubMed]

10. Pomari, E.; Piubelli, C.; Perandin, F.; Bisoffi, Z. Digital PCR: A new technology for diagnosis of parasitic infections. Clin. Microbiol. Infect. 2019, 25, 1510-1516. [CrossRef] [PubMed]

11. Morio, F.; Poirier, P.; Le Govic, Y.; Laude, A.; Valot, S.; Desoubeaux, G.; Argy, N.; Nourrisson, C.; Pomares, C.; Machouart, M.; et al. Assessment of the first commercial multiplex PCR kit (ParaGENIE Crypto-Micro Real-Time PCR) for the detection of Cryptosporidium spp., Enterocytozoon bieneusi, and Encephalitozoon intestinalis from fecal samples. Diagn. Microbiol. Infect. Dis. 2019, $95,34-37$. [CrossRef] [PubMed]

12. Wang, Y.; Zhang, B.; Li, J.; Yu, S.; Zhang, N.; Liu, S.; Zhang, Y.; Li, J.; Ma, N.; Cai, Y.; et al. Development of a Quantitative Real-Time PCR Assay for Detection of Cryptosporidium spp. Infection and Threatening Caused by Cryptosporidium parvum Subtype IIdA19G1 in Diarrhea Calves from Northeastern China. Vector Borne Zoonotic Dis. 2021, 21, 179-190. [CrossRef]

13. Shin, J.H.; Lee, S.E.; Kim, T.S.; Ma, D.W.; Cho, S.H.; Chai, J.Y.; Shin, E.H. Development of Molecular Diagnosis Using Multiplex Real-Time PCR and T4 Phage Internal Control to Simultaneously Detect Cryptosporidium parvum, Giardia lamblia, and Cyclospora cayetanensis from Human Stool Samples. Korean J. Parasitol. 2018, 56, 419-427. [CrossRef] [PubMed]

14. Higgins, J.A.; Fayer, R.; Trout, J.M.; Xiao, L.; Lal, A.A.; Kerby, S.; Jenkins, M.C. Real-time PCR for the detection of Cryptosporidium parvum. J. Microbiol. Methods 2001, 47, 323-337. [CrossRef]

15. Adamska, M.; Leońska-Duniec, A.; Maciejewska, A.; Sawczuk, M.; Skotarczak, B. PCR and real time PCR for the detection of Cryptosporidium parvum oocyst DNA. Folia Biol. 2011, 59, 115-120.

16. Burnet, J.B.; Ogorzaly, L.; Tissier, A.; Penny, C.; Cauchie, H.M. Novel quantitative TaqMan real-time PCR assays for detection of Cryptosporidium at the genus level and genotyping of major human and cattle-infecting species. J. Appl. Microbiol. 2013, 114, 1211-1222. [CrossRef]

17. Mary, C.; Chapey, E.; Dutoit, E.; Guyot, K.; Hasseine, L.; Jeddi, F.; Menotti, J.; Paraud, C.; Pomares, C.; Rabodonirina, M.; et al. ANOFEL Cryptosporidium National Network. Multicentric evaluation of a new real-time PCR assay for quantification of Cryptosporidium spp. and identification of Cryptosporidium parvum and Cryptosporidium hominis. J. Clin. Microbiol. 2013, 51, 2556-2563. [CrossRef] [PubMed]

18. Bouzid, M.; Elwin, K.; Nader, J.L.; Chalmers, R.M.; Hunter, P.R.; Tyler, K.M. Novel real-time PCR assays for the specific detection of human infective Cryptosporidium species. Virulence 2016, 7, 395-399. [CrossRef]

19. Cheun, H.I.; Kim, K.; Yoon, S.; Lee, W.J.; Park, W.Y.; Sim, S.; Yu, J.R. Cryptosporidium hominis infection diagnosed by real-time PCR-RFLP. Korean J. Parasitol. 2013, 51, 353-355. [CrossRef]

20. Amar, C.F.; Dear, P.H.; McLauchlin, J. Detection and identification by real time PCR/RFLP analyses of Cryptosporidium species from human faeces. Lett. Appl. Microbiol. 2004, 38, 217-222. [CrossRef]

21. Robinson, G.; Elwin, K.; Chalmers, R.M. Cryptosporidium Diagnostic Assays: Molecular Detection. Methods Mol. Biol. 2020, 2052, 11-22.

22. Hadfield, S.J.; Robinson, G.; Elwin, K.; Chalmers, R.M. Detection and differentiation of Cryptosporidium spp. in human clinical samples by use of real-time PCR. J. Clin. Microbiol. 2011, 49, 918-924. [CrossRef] [PubMed]

23. Stroup, S.E.; Roy, S.; Mchele, J.; Maro, V.; Ntabaguzi, S.; Siddique, A.; Kang, G.; Guerrant, R.L.; Kirkpatrick, B.D.; Fayer, R.; et al. Real-time PCR detection and speciation of Cryptosporidium infection using Scorpion probes. J. Med. Microbiol. 2006, 55 Pt 9 , 1217-1222. [CrossRef]

24. Jothikumar, N.; Hill, V.R. A novel photoinduced electron transfer (PET) primer technique for rapid real-time PCR detection of Cryptosporidium spp. Biochem. Biophys. Res. Commun. 2013, 436, 134-139. [CrossRef]

25. Haque, R.; Roy, S.; Siddique, A.; Mondal, U.; Rahman, S.M.; Mondal, D.; Houpt, E.; Petri, W.A., Jr. Multiplex real-time PCR assay for detection of Entamoeba histolytica, Giardia intestinalis, and Cryptosporidium spp. Am. J. Trop. Med. Hyg. 2007, 76, 713-717. [CrossRef]

26. Stroup, S.; Tongjai, S.; Swai, N.; Maro, A.; Kibiki, G.; Houpt, E.R. Dual probe DNA capture for sensitive real-time PCR detection of Cryptosporidium and Giardia. Mol. Cell. Probes. 2012, 26, 104-106. [CrossRef]

27. Stark, D.; Al-Qassab, S.E.; Barratt, J.L.; Stanley, K.; Roberts, T.; Marriott, D.; Harkness, J.; Ellis, J.T. Evaluation of multiplex tandem real-time PCR for detection of Cryptosporidium spp., Dientamoeba fragilis, Entamoeba histolytica, and Giardia intestinalis in clinical stool samples. J. Clin. Microbiol. 2011, 49, 257-262. [CrossRef] [PubMed]

28. Van Lint, P.; Rossen, J.W.; Vermeiren, S.; Ver Elst, K.; Weekx, S.; Van Schaeren, J.; Jeurissen, A. Detection of Giardia lamblia, Cryptosporidium spp. and Entamoeba histolytica in clinical stool samples by using multiplex real-time PCR after automated DNA isolation. Acta Clin. Belg. 2013, 68, 188-192. [CrossRef]

29. Madison-Antenucci, S.; Relich, R.F.; Doyle, L.; Espina, N.; Fuller, D.; Karchmer, T.; Lainesse, A.; Mortensen, J.E.; Pancholi, P.; Veros, W.; et al. Multicenter Evaluation of BD Max Enteric Parasite Real-Time PCR Assay for Detection of Giardia duodenalis, 
Cryptosporidium hominis, Cryptosporidium parvum, and Entamoeba histolytica. J. Clin. Microbiol. 2016, 54, 2681-2688. [CrossRef] [PubMed]

30. Goldfarb, D.M.; Dixon, B.; Moldovan, I.; Barrowman, N.; Mattison, K.; Zentner, C.; Baikie, M.; Bidawid, S.; Chan, F.; Slinger, R. Nanolitre real-time PCR detection of bacterial, parasitic, and viral agents from patients with diarrhoea in Nunavut, Canada. Int. J. Circumpolar Health 2013, 72, 19903. [CrossRef] [PubMed]

31. Mergen, K.; Espina, N.; Teal, A.; Madison-Antenucci, S. Detecting Cryptosporidium in Stool Samples Submitted to a Reference Laboratory. Am. J. Trop. Med. Hyg. 2020, 103, 421-427. [CrossRef] [PubMed]

32. Limor, J.R.; Lal, A.A.; Xiao, L. Detection and differentiation of Cryptosporidium parasites that are pathogenic for humans by real-time PCR. J. Clin. Microbiol. 2002, 40, 2335-2338. [CrossRef]

33. Godiwala, N.T.; Vandewalle, A.; Ward, H.D.; Leav, B.A. Quantification of in vitro and in vivo Cryptosporidium parvum infection by using real-time PCR. Appl. Environ. Microbiol. 2006, 72, 4484-4488. [CrossRef] [PubMed]

34. Köller, T.; Hahn, A.; Altangerel, E.; Verweij, J.J.; Landt, O.; Kann, S.; Dekker, D.; May, J.; Loderstädt, U.; Podbielski, A.; et al. Comparison of commercial and in-house real-time PCR platforms for 15 parasites and microsporidia in human stool samples without a gold standard. Acta Trop. 2020, 207, 105516. [CrossRef] [PubMed]

35. Won, E.J.; Kim, S.H.; Kee, S.J.; Shin, J.H.; Suh, S.P.; Chai, J.Y.; Ryang, D.W.; Shin, M.G. Multiplex Real-Time PCR Assay Targeting Eight Parasites Customized to the Korean Population: Potential Use for Detection in Diarrheal Stool Samples from Gastroenteritis Patients. PLoS ONE 2016, 11, e0166957. [CrossRef]

36. Hønsvall, B.K.; Robertson, L.J. Real-time nucleic acid sequence-based amplification (NASBA) assay targeting MIC1 for detection of Cryptosporidium parvum and Cryptosporidium hominis oocysts. Exp. Parasitol. 2017, 172, 61-67. [CrossRef]

37. Verweij, J.J.; Blangé, R.A.; Templeton, K.; Schinkel, J.; Brienen, E.A.; van Rooyen, M.A.; van Lieshout, L.; Polderman, A.M. Simultaneous detection of Entamoeba histolytica, Giardia lamblia, and Cryptosporidium parvum in fecal samples by using multiplex real-time PCR. J. Clin. Microbiol. 2004, 42, 1220-1223. [CrossRef] [PubMed]

38. Tanriverdi, S.; Tanyeli, A.; Başlamişli, F.; Köksal, F.; Kilinç, Y.; Feng, X.; Batzer, G.; Tzipori, S.; Widmer, G. Detection and genotyping of oocysts of Cryptosporidium parvum by real-time PCR and melting curve analysis. J. Clin. Microbiol. 2002, 40, 3237-3244. [CrossRef]

39. Amar, C.F.L.; Dear, P.H.; McLauchlin, J. Detection and genotyping by real-time PCR/RFLP analyses of Giardia duodenalis from human faeces. J. Med. Microbiol. 2003, 52 Pt 8, 681-683. [CrossRef]

40. Cunha, F.S.; Peralta, R.H.S.; Peralta, J.M. New insights into the detection and molecular characterization of Cryptosporidium with emphasis in Brazilian studies: A review. Rev. Inst. Med. Trop. Sao Paulo 2019, 61, e28. [CrossRef]

41. ten Hove, R.; Schuurman, T.; Kooistra, M.; Möller, L.; van Lieshout, L.; Verweij, J.J. Detection of diarrhoea-causing protozoa in general practice patients in The Netherlands by multiplex real-time PCR. Clin. Microbiol. Infect. 2007, 13, 1001-1007. [CrossRef] [PubMed]

42. Maas, L.; Dorigo-Zetsma, J.W.; de Groot, C.J.; Bouter, S.; Plötz, F.B.; van Ewijk, B.E. Detection of intestinal protozoa in paediatric patients with gastrointestinal symptoms by multiplex real-time PCR. Clin. Microbiol. Infect. 2014, 20, 545-550. [CrossRef] [PubMed]

43. Lamien-Meda, A.; Schneider, R.; Walochnik, J.; Auer, H.; Wiedermann, U.; Leitsch, D. A novel 5-Plex qPCR-HRM assay detecting human diarrheal parasites. Gut Pathog. 2020, 12, 27. [CrossRef] [PubMed]

44. Zebardast, N.; Yeganeh, F.; Gharavi, M.J.; Abadi, A.; Tabaei, S.J.S.; Haghighi, A. Simultaneous detection and differentiation of Entamoeba histolytica, E. dispar, E. moshkovskii, Giardia lamblia and Cryptosporidium spp. in human fecal samples using multiplex PCR and qPCR-MCA. Acta Trop. 2016, 162, 233-238. [CrossRef] [PubMed]

45. Van den Bossche, D.; Cnops, L.; Verschueren, J.; Van Esbroeck, M. Comparison of four rapid diagnostic tests, ELISA, microscopy and PCR for the detection of Giardia lamblia, Cryptosporidium spp. and Entamoeba histolytica in feces. J. Microbiol. Methods 2015, 110, 78-84. [CrossRef] [PubMed]

46. Parr, J.B.; Sevilleja, J.E.; Samie, A.; Alcantara, C.; Stroup, S.E.; Kohli, A.; Fayer, R.; Lima, A.A.; Houpt, E.R.; Guerrant, R.L. Detection and quantification of Cryptosporidium in HCT-8 cells and human fecal specimens using real-time polymerase chain reaction. Am. J. Trop. Med. Hyg. 2007, 76, 938-942. [CrossRef] [PubMed]

47. Shrivastava, A.K.; Panda, S.; Kumar, S.; Sahu, P.S. Two novel genomic DNA sequences as common diagnostic targets to detect Cryptosporidium hominis and Cryptosporidium parvum: Development of quantitative polymerase chain reaction assays, and clinical evaluation. Indian J. Med. Microbiol. 2020, 38, 430-439. [CrossRef] [PubMed]

48. Fontaine, M.; Guillot, E. Development of a TaqMan quantitative PCR assay specific for Cryptosporidium parvum. FEMS Microbiol. Lett. 2002, 214, 13-17. [CrossRef]

49. Zhan, Z.; Guo, J.; Xiao, Y.; He, Z.; Xia, X.; Huang, Z.; Guan, H.; Ling, X.; Li, J.; Diao, B.; et al. Comparison of BioFire FilmArray gastrointestinal panel versus Luminex xTAG Gastrointestinal Pathogen Panel (xTAG GPP) for diarrheal pathogen detection in China. Int. J. Infect. Dis. 2020, 99, 414-420. [CrossRef]

50. Mejia, R.; Vicuña, Y.; Broncano, N.; Sandoval, C.; Vaca, M.; Chico, M.; Cooper, P.J.; Nutman, T.B. A novel, multi-parallel, real-time polymerase chain reaction approach for eight gastrointestinal parasites provides improved diagnostic capabilities to resource-limited at-risk populations. Am. J. Trop. Med. Hyg. 2013, 88, 1041-1047. [CrossRef]

51. Jothikumar, N.; da Silva, A.J.; Moura, I.; Qvarnstrom, Y.; Hill, V.R. Detection and differentiation of Cryptosporidium hominis and Cryptosporidium parvum by dual TaqMan assays. J. Med. Microbiol. 2008, 57 Pt 9, 1099-1105. [CrossRef] 
52. Khalil, S.; Mirdha, B.R.; Paul, J.; Panda, A.; Makharia, G.; Chaudhry, R.; Bhatnagar, S. Development and evaluation of molecular methods for detection of Cryptosporidium spp. in human clinical samples. Exp. Parasitol. 2016, 170, 207-213. [CrossRef]

53. Taniuchi, M.; Verweij, J.J.; Noor, Z.; Sobuz, S.U.; Lieshout, L.v.; Petri, W.A., Jr.; Haque, R.; Houpt, E.R. High throughput multiplex PCR and probe-based detection with Luminex beads for seven intestinal parasites. Am. J. Trop. Med. Hyg. 2011, 84, 332-337. [PubMed]

54. Hartmeyer, G.N.; Hoegh, S.V.; Skov, M.N.; Dessau, R.B.; Kemp, M. Selecting PCR for the Diagnosis of Intestinal Parasitosis: Choice of Targets, Evaluation of In-House Assays, and Comparison with Commercial Kits. J. Parasitol. Res. 2017, $2017,6205257$. [CrossRef]

55. Liu, J.; Gratz, J.; Amour, C.; Kibiki, G.; Becker, S.; Janaki, L.; Verweij, J.J.; Taniuchi, M.; Sobuz, S.U.; Haque, R.; et al. A laboratorydeveloped TaqMan Array Card for simultaneous detection of 19 enteropathogens. J. Clin. Microbiol. 2013, 51, 472-480. [CrossRef] [PubMed]

56. Wessels, E.; Rusman, L.G.; van Bussel, M.J.; Claas, E.C. Added value of multiplex Luminex gastrointestinal Pathogen Panel (xTAG®GPP) testing in the diagnosis of infectious gastroenteritis. Clin. Microbiol. Infect. 2014, 20, O182-O187. [PubMed]

57. ten Hove, R.J.; van Esbroeck, M.; Vervoort, T.; van den Ende, J.; van Lieshout, L.; Verweij, J.J. Molecular diagnostics of intestinal parasites in returning travellers. Eur. J. Clin. Microbiol. Infect. Dis. 2009, 28, 1045-1053. [CrossRef] [PubMed]

58. Parčina, M.; Reiter-Owona, I.; Mockenhaupt, F.P.; Vojvoda, V.; Gahutu, J.B.; Hoerauf, A.; Ignatius, R. Highly sensitive and specific detection of Giardia duodenalis, Entamoeba histolytica, and Cryptosporidium spp. in human stool samples by the BD MAX ${ }^{\mathrm{TM}}$ Enteric Parasite Panel. Parasitol. Res. 2018, 117, 447-451. [CrossRef]

59. Schuurs, T.A.; Koelewijn, R.; Brienen, E.A.T.; Kortbeek, T.; Mank, T.G.; Mulder, B.; Stelma, F.F.; van Lieshout, L.; van Hellemond, J.J. Harmonization of PCR-based detection of intestinal pathogens: Experiences from the Dutch external quality assessment scheme on molecular diagnosis of protozoa in stool samples. Clin. Chem. Lab. Med. 2018, 56, 1722-1727.

60. Tanriverdi, S.; Arslan, M.O.; Akiyoshi, D.E.; Tzipori, S.; Widmer, G. Identification of genotypically ixed Cryptosporidium parvum populations in humans and calves. Mol. Biochem. Parasitol. 2003, 130, 13-22. [CrossRef]

61. Puebla, L.E.J.; Núñez-Fernández, F.A.; Nodarse, J.F.; Millán, I.A.; Rodríguez, I.C.; Silva, I.M.; Valdés, L.A.; Robertson, L.J. Diagnosis of intestinal protozoan infections in patients in Cuba by microscopy and molecular methods: Advantages and disadvantages. J. Microbiol. Methods 2020, 179, 106102. [CrossRef] [PubMed]

62. Shaposhnik, E.G.; Abozaid, S.; Grossman, T.; Marva, E.; On, A.; Azrad, M.; Peretz, A. The Prevalence of Cryptosporidium among Children Hospitalized because of Gastrointestinal Symptoms and the Efficiency of Diagnostic Methods for Cryptosporidium. Am. J. Trop. Med. Hyg. 2019, 101, 160-163. [CrossRef]

63. Calderaro, A.; Montecchini, S.; Gorrini, C.; Dettori, G.; Chezzi, C. Similar diagnostic performances of antigen detection and nucleic acid detection of Cryptosporidium spp. in a low-prevalence setting. Diagn. Microbiol. Infect. Dis. 2011, 70, 72-77. [CrossRef] [PubMed]

64. Chalmers, R.M.; Campbell, B.M.; Crouch, N.; Charlett, A.; Davies, A.P. Comparison of diagnostic sensitivity and specificity of seven Cryptosporidium assays used in the UK. J. Med. Microbiol. 2011, 60 Pt 11, 1598-1604. [CrossRef]

65. Elsafi, S.H.; Al-Maqati, T.N.; Hussein, M.I.; Adam, A.A.; Hassan, M.M.; Al Zahrani, E.M. Comparison of microscopy, rapid immunoassay, and molecular techniques for the detection of Giardia lamblia and Cryptosporidium parvum. Parasitol. Res. 2013, 112, 1641-1646. [CrossRef] [PubMed]

66. Johansen, Ø.H.; Abdissa, A.; Zangenberg, M.; Mekonnen, Z.; Eshetu, B.; Bjørang, O.; Alemu, Y.; Sharew, B.; Langeland, N.; Robertson, L.J.; et al. Performance and operational feasibility of two diagnostic tests for cryptosporidiosis in children (CRYPTO-POC): A clinical, prospective, diagnostic accuracy study. Lancet Infect. Dis. 2021, 21, 722-730.

67. van Coppenraet, L.E.B.; Wallinga, J.A.; Ruijs, G.J.; Bruins, M.J.; Verweij, J.J. Parasitological diagnosis combining an internally controlled real-time PCR assay for the detection of four protozoa in stool samples with a testing algorithm for microscopy. Clin. Microbiol. Infect. 2009, 15, 869-874. [CrossRef] [PubMed]

68. Koltas, I.S.; Elgun, G.; Demirkazık, M. The importance of Real-Time Polymerase Chain Reaction method in diagnosis of intestinal parasites in cases with diarrhea. Trop. Biomed. 2017, 34, 895-902.

69. Velásquez, J.N.; Pantano, M.L.; Vittar, N.; Nigro, M.G.; Figueiras, O.; Astudillo, O.G.; Ricart, J.; Della Paolera, D.; Carnevale, S. First detection of Cryptosporidium DNA in blood and cerebrospinal fluid of HIV-infected patients. Parasitol. Res. 2018, 117, 875-881. [CrossRef] [PubMed]

70. Mero, S.; Kirveskari, J.; Antikainen, J.; Ursing, J.; Rombo, L.; Kofoed, P.E.; Kantele, A. Multiplex PCR detection of Cryptosporidium $\mathrm{sp}$, Giardia lamblia and Entamoeba histolytica directly from dried stool samples from Guinea-Bissauan children with diarrhoea. Infect. Dis. 2017, 49, 655-663. [CrossRef] [PubMed]

71. Natarajan, G.; Kabir, M.; Perin, J.; Hossain, B.; Debes, A.; Haque, R.; George, C.M. Whatman Protein Saver Cards for Storage and Detection of Parasitic Enteropathogens. Am. J. Trop. Med. Hyg. 2018, 99, 1613-1618. [CrossRef] [PubMed]

72. O'Leary, J.K.; Blake, L.; Corcoran, D.; Elwin, K.; Chalmers, R.; Lucey, B.; Sleator, R.D. Cryptosporidium spp. surveillance and epidemiology in Ireland: A longitudinal cohort study employing duplex real-time PCR based speciation of clinical cases. J. Clin. Pathol. 2020, 73, 758-761. [CrossRef]

73. Nazeer, J.T.; Khalifa, K.E.S.; von Thien, H.; El-Sibaei, M.M.; Abdel-Hamid, M.Y.; Tawfik, R.A.; Tannich, E. Use of multiplex real-time PCR for detection of common diarrhea causing protozoan parasites in Egypt. Parasitol. Res. 2013, 112, 595-601. [CrossRef] 
74. Velasco, J.M.; Yoon, I.K.; Mason, C.J.; Jarman, R.G.; Bodhidatta, L.; Klungthong, C.; Silapong, S.; Valderama, M.T.; Wongstitwilairoong, T.; Torres, A.G.; et al. Applications of PCR (real-time and MassTag) and enzyme-linked immunosorbent assay in diagnosis of respiratory infections and diarrheal illness among deployed U.S. military personnel during exercise Balikatan 2009, Philippines. Mil. Med. 2011, 176, 1096-1100. [CrossRef]

75. Efunshile, M.A.; Ngwu, B.A.; Kurtzhals, J.A.; Sahar, S.; König, B.; Stensvold, C.R. Molecular Detection of the Carriage Rate of Four Intestinal Protozoa with Real-Time Polymerase Chain Reaction: Possible Overdiagnosis of Entamoeba histolytica in Nigeria. Am. J. Trop. Med. Hyg. 2015, 93, 257-262. [CrossRef] [PubMed]

76. Incani, R.N.; Ferrer, E.; Hoek, D.; Ramak, R.; Roelfsema, J.; Mughini-Gras, L.; Kortbeek, T.; Pinelli, E. Diagnosis of intestinal parasites in a rural community of Venezuela: Advantages and disadvantages of using microscopy or RT-PCR. Acta Trop. 2017, 167, 64-70. [CrossRef]

77. Ögren, J.; Dienus, O.; Matussek, A. Optimization of routine microscopic and molecular detection of parasitic protozoa in SAF-fixed faecal samples in Sweden. Infect. Dis. 2020, 52, 87-96. [CrossRef] [PubMed]

78. Elwin, K.; Robinson, G.; Hadfield, S.J.; Fairclough, H.V.; Iturriza-Gómara, M.; Chalmers, R.M. A comparison of two approaches to extracting Cryptosporidium DNA from human stools as measured by a real-time PCR assay. J. Microbiol. Methods 2012, 89, 38-40. [CrossRef]

79. Valeix, N.; Costa, D.; Basmaciyan, L.; Valot, S.; Vincent, A.; Razakandrainibe, R.; Robert-Gangneux, F.; Nourrisson, C.; Pereira, B.; Fréalle, E.; et al. Multicenter Comparative Study of Six Cryptosporidium parvum DNA Extraction Protocols Including Mechanical Pretreatment from Stool Samples. Microorganisms 2020, 8, 1450. [CrossRef]

80. Halstead, F.D.; Lee, A.V.; Couto-Parada, X.; Polley, S.D.; Ling, C.; Jenkins, C.; Chalmers, R.M.; Elwin, K.; Gray, J.J.; Iturriza-Gómara, M.; et al. Universal extraction method for gastrointestinal pathogens. J. Med. Microbiol. 2013, 62 Pt 10, 1535-1539. [CrossRef]

81. Claudel, L.; Valeix, N.; Basmaciyan, L.; Pereira, B.; Costa, D.; Vincent, A.; Valot, S.; Favennec, L.; Dalle, F. Comparative Study of Eleven Mechanical Pretreatment Protocols for Cryptosporidium parvum DNA Extraction from Stool Samples. Microorganisms 2021, 9, 297. [CrossRef] [PubMed]

82. Hoffmann, T.; Hahn, A.; Verweij, J.J.; Leboulle, G.; Landt, O.; Strube, C.; Kann, S.; Dekker, D.; May, J.; Frickmann, H.; et al. Differing Effects of Standard and Harsh Nucleic Acid Extraction Procedures on Diagnostic Helminth Real-Time PCRs Applied to Human Stool Samples. Pathogens 2021, 10, 188. [CrossRef] [PubMed]

83. Woolsey, I.D.; Blomstrand, B.; Øines, Ø.; Enemark, H.L. Assessment of differences between DNA content of cell-cultured and freely suspended oocysts of Cryptosporidium parvum and their suitability as DNA standards in qPCR. Parasites Vectors 2019, 12, 596. [CrossRef] [PubMed]

84. Paziewska-Harris, A.; Schoone, G.; Schallig, H.D. An easy 'one tube' method to estimate viability of Cryptosporidium oocysts using real-time qPCR. Parasitol. Res. 2016, 115, 2873-2877. [CrossRef]

85. Fontaine, M.; Guillot, E. Study of $18 \mathrm{~S}$ rRNA and rDNA stability by real-time RT-PCR in heat-inactivated Cryptosporidium parvum oocysts. FEMS Microbiol. Lett. 2003, 226, 237-243. [CrossRef]

86. Zautner, A.E.; Groß, U.; Emele, M.F.; Hagen, R.M.; Frickmann, H. More Pathogenicity or Just More Pathogens?-On the Interpretation Problem of Multiple Pathogen Detections with Diagnostic Multiplex Assays. Front. Microbiol. 2017, 8, 1210. [CrossRef] [PubMed]

87. Elfving, K.; Andersson, M.; Msellem, M.I.; Welinder-Olsson, C.; Petzold, M.; Björkman, A.; Trollfors, B.; Mårtensson, A.; Lindh, M. Real-time PCR threshold cycle cutoffs help to identify agents causing acute childhood diarrhea in Zanzibar. J. Clin. Microbiol. 2014, 52, 916-923. [CrossRef]

88. Rogawski, E.T.; Liu, J.; Platts-Mills, J.A.; Kabir, F.; Lertsethtakarn, P.; Siguas, M.; Khan, S.S.; Praharaj, I.; Murei, A.; Nshama, R.; et al. Use of quantitative molecular diagnostic methods to investigate the effect of enteropathogen infections on linear growth in children in low-resource settings: Longitudinal analysis of results from the MAL-ED cohort study. Lancet Glob. Health 2018, 6, e1319-e1328. [CrossRef]

89. Schotte, U.; Hoffmann, T.; Schwarz, N.G.; Rojak, S.; Lusingu, J.; Minja, D.; Kaseka, J.; Mbwana, J.; Gesase, S.; May, J.; et al. Study of enteric pathogens among children in the tropics and effects of prolonged storage of stool samples. Lett. Appl. Microbiol. 2021, 72, 774-782. [CrossRef] [PubMed]

90. Platts-Mills, J.A.; Gratz, J.; Mduma, E.; Svensen, E.; Amour, C.; Liu, J.; Maro, A.; Saidi, Q.; Swai, N.; Kumburu, H.; et al. Association between stool enteropathogen quantity and disease in Tanzanian children using TaqMan array cards: A nested case-control study. Am. J. Trop. Med. Hyg. 2014, 90, 133-138.

91. Verweij, J.J.; Stensvold, C.R. Molecular testing for clinical diagnosis and epidemiological investigations of intestinal parasitic infections. Clin. Microbiol. Rev. 2014, 27, 371-418.

92. Guy, R.A.; Payment, P.; Krull, U.J.; Horgen, P.A. Real-time PCR for quantification of Giardia and Cryptosporidium in environmental water samples and sewage. Appl. Environ. Microbiol. 2003, 69, 5178-5185.

93. Laxer, M.A.; Timblin, B.K.; Patel, R.J. DNA sequences for the specific detection of Cryptosporidium parvum by the polymerase chain reaction. Am. J. Trop. Med. Hyg. 1991, 45, 688-694. [PubMed]

94. Tanida, K.; Hahn, A.; Eberhardt, K.A.; Tannich, E.; Landt, O.; Kann, S.; Feldt, T.; Sarfo, F.S.; Di Cristanziano, V.; Frickmann, H.; et al. Comparative Assessment of In-House Real-Time PCRs Targeting Enteric Disease-Associated Microsporidia in Human Stool Samples. Pathogens 2021, 10, 656. [PubMed] 
95. Hahn, A.; Podbielski, A.; Meyer, T.; Zautner, A.E.; Loderstädt, U.; Schwarz, N.G.; Krüger, A.; Cadar, D.; Frickmann, H. On detection thresholds-a review on diagnostic approaches in the infectious disease laboratory and the interpretation of their results. Acta Trop. 2020, 205, 105377. [PubMed]

96. Qu, Y.; Tan, M.; Kutner, M.H. Random effects models in latent class analysis for evaluating accuracy of diagnostic tests. Biometrics 1996, 52, 797-810.

97. Eberhardt, K.A.; Sarfo, F.S.; Dompreh, A.; Kuffour, E.O.; Geldmacher, C.; Soltau, M.; Schachscheider, M.; Drexler, J.F.; EisHübinger, A.M.; Häussinger, D.; et al. Helicobacter pylori Coinfection Is Associated with Decreased Markers of Immune Activation in ART-Naive HIV-Positive and in HIV-Negative Individuals in Ghana. Clin. Infect. Dis. 2015, 61, 1615-1623. [PubMed]

98. Sarfo, F.S.; Eberhardt, K.A.; Dompreh, A.; Kuffour, E.O.; Soltau, M.; Schachscheider, M.; Drexler, J.F.; Eis-Hübinger, A.M.; Häussinger, D.; Oteng-Seifah, E.E.; et al. Helicobacter pylori Infection Is Associated with Higher CD4 T Cell Counts and Lower HIV-1 Viral Loads in ART-Naïve HIV-Positive Patients in Ghana. PLoS ONE 2015, 10, e0143388.

99. Blohm, M.; Hahn, A.; Hagen, R.M.; Eberhardt, K.A.; Rohde, H.; Leboulle, G.; Feldt, T.; Sarfo, F.S.; Di Cristanziano, V.; Frickmann, H.; et al. Comparison of Two Real-Time PCR Assays Targeting Ribosomal Sequences for the Identification of Cystoisospora belli in Human Stool Samples. Pathogens 2021, 10, 1053.

100. Bossuyt, P.M.; Reitsma, J.B.; Bruns, D.E.; Gatsonis, C.A.; Glasziou, P.P.; Irwig, L.; Lijmer, J.G.; Moher, D.; Rennie, D.; De Vet, H.C.W.; et al. STARD 2015: An updated list of essential items for reporting diagnostic accuracy studies. BMJ 2015, 351 , h5527.

101. Niesters, H.G. Quantitation of Viral Load Using Real-Time Amplification Techniques. Methods 2001, 25, 419-429. [CrossRef] [PubMed]

102. Landis, J.R.; Koch, G.G. The Measurement of Observer Agreement for Categorical Data. Biometrics 1977, 33, 159-174. [CrossRef] [PubMed]

103. Frickmann, H.; Hinz, R.; Hagen, R.M. Comparison of an automated nucleic acid extraction system with the column-based procedure. Eur. J. Microbiol. Immunol. 2015, 5, 94-102.

104. Schawaller, M.; Wiemer, D.; Hagen, R.M.; Frickmann, H. Infectious diseases in German military personnel after predominantly tropical deployments: A retrospective assessment over 13 years. BMJ Mil. Health 2020. [CrossRef] [PubMed]

105. Frickmann, H.; Warnke, P.; Frey, C.; Schmidt, S.; Janke, C.; Erkens, K.; Schotte, U.; Köller, T.; Maaßen, W.; Podbielski, A.; et al. Surveillance of Food- and Smear-Transmitted Pathogens in European Soldiers with Diarrhea on Deployment in the Tropics: Experience from the European Union Training Mission (EUTM) Mali. Biomed. Res. Int. 2015, 2015, 573904. [CrossRef] [PubMed]

106. Frickmann, H.; Schwarz, N.G.; Wiemer, D.F.; Fischer, M.; Tannich, E.; Scheid, P.L.; Müller, M.; Schotte, U.; Bock, W.; Hagen, R.M. Food and drinking water hygiene and intestinal protozoa in deployed German soldiers. Eur. J. Microbiol. Immunol. 2013, 3, 53-60. [CrossRef] 